\title{
Role of Calcium and Protein Kinase $G$ in the Activation of T Cells in Takayasu's Arteritis
}

\author{
Jyoti Dhar, Ph. D., Nirmal K. Ganguly, M.D., \\ Savita KUMARI, M.D.,* \\ and Bal Krishan SHARMA, M.D.*
}

\section{Summary}

The roles of protein kinase $\mathrm{C}$ and calcium in the $\mathrm{T}$ cells of patients suffering from Takayasu's arteritis (TA) in response to the mitogens phorbolmyristate acetate (PMA) and streptococcal antigens have been studied. In TA there was an increased basal activity of protein kinase $C(1.074 \pm 0.223$ $\mathrm{nmoles} / \mathrm{mg}$ protein $/ \mathrm{min})$ as compared with that of controls $(0.570 \pm .12)$ $(p<0.001)$. There was $75 \%$ translocation from the cytosol to membrane fraction in response to PMA. Intracellular calcium levels showed increased basal levels in TA (177.07 \pm 12.56 nmoles) compared with the controls (112.83 \pm 10.6 nmoles) $(p<0.001)$ and there was a further rise on stimulation, indicating the $T$ cells were in an activated state. There was a positive correlation between the calcium levels and the activity of protein kinase $\mathrm{C}(r=0.71$, $p<0.05)$. Unlike the situation in patients with rheumatic fever, $\mathrm{T}$ cells in TA showed no stimulation in response to streptococcal antigens. The low level of cAMP (1.12 \pm 0.169 pmoles/million cells) compared with that of controls $(1.4 \pm 0.03)$ further supports the role of $\mathrm{PKC}$-calcium in the $\mathrm{T}$ cell activation process. These findings suggest activation of the PKC-calcium pathway in TA. (Jpn Heart J 36: 341-348, 1995)

Key words: Protein kinase C Intracellular calcium Takayasu's arteritis Signal transduction

7 AKAYASU arteritis (TA) is a chronic inflammatory arteriopathy of unknown etiology affecting large vessels, particularly the aorta and its main branches and to a lesser extent the pulmonary and coronary arteries. The early case descriptions were those of Davy, ${ }^{1)}$ Savoury ${ }^{2)}$ and Kussmaul. ${ }^{3)}$ The disease occurs in almost all parts of the world, with a majority of cases occurring in Japan, South East Asia, Africa and Mexico. We have reported TA to be the most common cause of renovascular hypertension in India (Sharma et al) ${ }^{4)}$ and this is

From Department of Experimental Medicine and Biotechnology and *Internal Medicine, Postgraduate Institute of Medical Education and Research, Chandigarh, India.

Address for correspondence: B.K. Sharma, M.D., Professor and Head, Department of Internal Medicine, Postgraduate Institute of Medical Education and Research, Chandigarh 160012 India.

Received for publication October 5, 1994.

Accepted February 8, 1995. 
true of other South Asian countries including China (Dong et al), ${ }^{5)}$ Thailand (Vinijchaikul et al) ${ }^{6)}$ and Japan (Koide et al). ${ }^{7)}$

The etiology of TA has been linked to various autoimmune diseases such as SLE, polymyositis, and rheumatoid arthritis and infections such as tuberculosis. Some studies suggested a streptococcal etiology on the basis of raised antistreptolysin levels (Birke et al, ${ }^{87}$ Sandring et $\mathrm{al}^{9 \%}$ ). Ask-Upmark while reviewing cases of TA outside Japan observed clinical evidence of rheumatic fever in many cases. ${ }^{10)}$

Several lines of evidence point to $\mathrm{TA}$ as a consequence of immunologic dysfunction. Defective $\mathrm{T}$ lymphocyte function, an increase in serum levels of IgG and a reduction in serum compliment constituents $\mathrm{C}_{3}$ and $\mathrm{C}_{4}$, indicating the possibility of formation of complement binding immune complex, have been reported (Gupta et al). ${ }^{11}$ Circulating lymphocytes have been shown to be cytotoxic towards human endothelial cells of the umbilical cord (Scot et al). ${ }^{12}$

There is no information available in the literature regarding any change in the signal transduction in $\mathbf{T}$ lymphocytes in this disease. In this study we have examined the second messengers calcium and protein kinase $\mathrm{G}(\mathrm{PKC})$ in the $\mathrm{T}$ lymphocyte in TA. There is a prior binding of ligand/agonist/antigen to the TCR receptor on the $T$ cell membrane which results in a breakdown of phosphoinositides leading to the formation of inositol triphosphate (IP3) and diacylglycerol (DAG). DAG activates $\mathrm{PKC}$ and releases calcium from intracellular stores. ${ }^{13)}$ Activation of PKC and an increase in intracellular calcium culminate in $T$ cell activation. Besides studying $T$ cell activation by the non-specific mitogen, phytohemagglutinin (PHA), and phorbol myristate acetate (PMA), which is an intracellular activator, we have also used the streptococcal cross reactive antigens to establish any possible link of streptococcal infection with TA.

\section{Materials and Methods}

Patients/subjects: Twenty patients with TA confirmed by angiography, and with a female to male ratio of $4: 1$ and age range of 10-38 yrs were diagnosed by Ishikawa's criteria. ${ }^{14)} \mathrm{A}$ group of 10 patients with acute rheumatic fever diagnosed by Jones' criteria ${ }^{15)}$ and ten age and sex matched controls were also studied.

Sample collection: Blood sampling from these patients was done at the time of first examination and after three months.

Antigen preparation: M-5 strain of group A beta hemolytic streptococcus was obtained from the WHO Streptococcal Research Reference Laboratory, Prague.

Streptococcal membrane antigen (MAG) was isolated by the method of Friemer and Zabriskie, ${ }^{16)}$ as modified by Heymar ${ }^{(7)}$ using group A M-5 betahemolytic streptococci. The rhamnose and $\mathrm{N}$-acetyl glucosamine contents of 
the membranes were determined by the methods of Dische and Shettles ${ }^{18)}$ and Rondle and Morgan, ${ }^{19)}$ respectively.

The group specific carbohydrate antigen (CHO) was prepared from M-5 streptococcal strain by conventional Fuller's method. ${ }^{20)}$

Cell isolation: Peripheral blood mononuclear cells were separated from heparinized venous blood of patients/subjects by density centrifugation (Boyum). ${ }^{21)}$ The resulting cell suspension was incubated in plastic dishes at $37^{\circ} \mathrm{C}$ for $1 \mathrm{hr}$ and nonadherent cells were recovered. $T$ cells were enriched by a nylon wool column as described by Julius et al. ${ }^{22}$ These enriched $T$ cells reacted with anti CD3 monoclonal antibody, and viability was checked by the trypan blue exclusion test. More than $95 \%$ were found to be normal and active.

Protein kinase $\mathbf{C}$ preparation: Unstimulated or PMA (2 nM), MAG $\langle 0.01$ $\mathrm{mg} / \mathrm{ml})$ and $\mathrm{CHO}(0.01 \mathrm{mg} / \mathrm{ml})$ stimulated T cells were washed twice with PBS. Unstimulated cells were resuspended in buffer A containing $20 \mathrm{mM}$ Tris $\mathrm{HCl}(\mathrm{pH} 7.5), 2 \mathrm{mM}$ EDTA, $5 \mathrm{mM}$ EGTA, $2 \mathrm{mM}$ PMSF, $25 \mathrm{ng} / \mathrm{m} /$ leupeptin and were sonicated with three bursts of 75 to $80 \mathrm{w}$ for 5 seconds. The homogenates were centrifuged at $100,000 \mathrm{~g}$ for $1 \mathrm{hr}$ at $4^{\circ} \mathrm{C}$. The cytosolic supernatant was collected and the detergent extractable fraction prepared from the pellet by homogenizing in buffer A containing $10 \mathrm{mM}$ EGTA and $0.2 \%$ TX 100 . This fraction included all the membrane associated proteins. PKC from cytosolic and particulate fractions was partially purified by applying each sample to a $1.5 \mathrm{~m} l$ DEAE sepharose column equilibrated with buffer $A$. The column was washed with $5 \mathrm{~m} l$ buffer $A$ and $0.5 \mathrm{ml} 0.15 \mathrm{M} \mathrm{NaCl}$ and eluted with $2 \mathrm{~m} l$ of $0.15 \mathrm{M} \mathrm{NaCl}$. All of the PKC activity was present in this fraction.

PKC assay: The assay was performed as described by Yamauchi et al. ${ }^{23)}$ The standard reaction mixture contained $20 \mathrm{mM}$ Tris $\mathrm{HCl}(\mathrm{pH} 7.5), 0.75 \mathrm{mM} \mathrm{CaCl}_{2}$, $10 \mathrm{mM} \mathrm{Mg}$ acetate, $1 \mathrm{nM} \mathrm{P}^{32}$ ATP (BARC), $25 \mu \mathrm{g}$ Histone III AS (Sigma) and $50 \mu \mathrm{g} / \mathrm{m} /$ leupeptin with or without phosphatidyl serine in a $250 \mu l$ final volume. Incubation was carried out for $1 \mathrm{~min}$ at $30^{\circ} \mathrm{C}$. The reaction was terminated by addition of $25 \%$ TCA. The acid precipitate was collected by filtration over a millipore filter $(.45 \mu \mathrm{m})$. Filters were washed with cold $5 \%$ TCA and then dissolved in a scintillation fluid and counted for radioactivity on an LKB beta counter. PKC activity was determined by subtracting the amount of $\mathrm{P}^{32}$ incorporation to histone noted in the absence or presence of phosphatidyl serine. Kinase activity was expressed as nmoles/mg protein/min.

Intracellular calcium: Intracellular calcium was measured as described by Hoffman et al. ${ }^{24)}$ Unstimulated and stimulated $\mathrm{T}$ cells were incubated for $30 \mathrm{~min}$ in complete media and $5 \mu \mathrm{M}$ Fura $2 \mathrm{AM}\left(5 \times 10^{6}\right.$ cells $\left./ \mathrm{ml}\right)$ with various streptococcal antigens and mitogens such as $\mathrm{PHA} 0.1 \%$. After centrifugation $1 \times 10^{6}$ cells $/ \mathrm{m} l$ were suspended in HEPES buffer $(145 \mathrm{mM} \mathrm{NaCl}, 5 \mathrm{mM} \mathrm{KGl}$, 


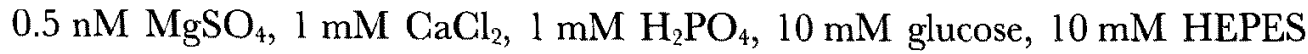
$\mathrm{pH} 7.6$ at $20^{\circ} \mathrm{C}$ ). The cytoplasmic free calcium was determined by fluorescence measurements at $37^{\circ} \mathrm{C}$ with monochromatic settings of $500 \mathrm{~nm}$ emission and 340 $\mathrm{nm}$ excitation in a spectrofluorometer using the equation $\left(\mathrm{Ca}^{2+}\right) \mathrm{i}=224 \mathrm{x}(\mathrm{F}-$ Fmin) / (5 max-F) in which $224 \mathrm{~nm}$ is the apparent dissociation constant for calcium and Fura 2.

cAMP assay: This assay was carried out using a commercial scintillation proximity radioimmunoassay kit (Amersham) and the manufacturer's protocol was followed.

Statistical analysis was done by analysis of variance. Student's ' $t$ ' test was used to study further significance. Karl Pearson's coefficient was used to determine the correlations.

\section{Results}

The total PKC activity was predominantly found in the cytosolic fraction of the unstimulated $\mathrm{T}$ cells. The PKC levels ranged from $0.871-1.57 \mathrm{nmoles} / \mathrm{mg}$ $\mathrm{prot} / \mathrm{min}$ in the unstimulated cells. It was observed that basal PKC in unstimulated cells was significantly higher $(p<0.001)$ in TA as compared to controls (Table I).

In response to the intracellular activator, PMA, which induces translocation of PKC from the cytosol to the particulate fraction, there was a redistribution of PKC. The enzyme was translocated to the membrane fraction in all cases but the translocation seen in TA patients was $75 \%$ as compared with $39 \%$ in the controls (Table II). When both streptococcal antigens were added, the translocation was much more in the group with acute rheumatic fever as compared to TA and controls (Table II), showing presensitization of the former group to streptococcal antigens.

Intracellular calcium levels: Basal intracellular calcium in $T$ lymphocytes was

Table I. PKC Levels as Expressed in nanomoles $/ \mathrm{mg}$ protein $/ \mathrm{min}$

\begin{tabular}{|c|c|c|c|c|c|c|c|c|}
\hline \multirow{2}{*}{ Groups } & \multicolumn{2}{|c|}{ Unstimulated } & \multicolumn{2}{|c|}{ PMA } & \multicolumn{2}{|c|}{ MAG } & \multicolumn{2}{|c|}{$\mathrm{CHO}$} \\
\hline & Cytosolic & Particulate & Cytosolic & Particulate & Cytosolic & Particulate & Cytosolic & Particulate \\
\hline \multirow[t]{2}{*}{ TA } & $1.07 \pm .22$ & $0.053 \pm .02$ & $0.266 \pm .05$ & $0.807 \pm .16^{* * *}$ & $0.956 \pm .17$ & $0.095 \pm .05$ & $0.976 \pm .23$ & $0.073 \pm .02$ \\
\hline & $1.08 \pm .18$ & $0.075 \pm .01$ & $0.206 \pm .06$ & $0.883 \pm .13^{* *}$ & $0.984 \pm .14$ & $0.086 \pm .01$ & $1.00 \pm .14$ & $0.083 \pm .01$ \\
\hline \multirow[t]{2}{*}{$\mathrm{ARF}$} & $1.91 \pm .41$ & $0.059 \pm .02$ & $0.669 \pm .24$ & $1.204 \pm .22^{* *}$ & $0.596 \pm .15$ & $1.27 \pm .299 * *$ & * $0.56 \pm .15$ & $1.10 \pm 15 * *$ \\
\hline & $1.13 \pm .10$ & $0.052 \pm .02$ & $0.28 \pm .08$ & $0.823 \pm .11^{* *}$ & $0.345 \pm .04$ & $0.728 \pm .14^{* * *}$ & $0.589 \pm .07$ & $0.595 \pm .005 * *$ \\
\hline Controls & $0.570 \pm .12$ & $0.031 \pm .01$ & $0.331 \pm .08$ & $0.207 \pm .05$ & $0.510 \pm .11$ & $0.085 \pm .03$ & $0.580 \pm .13$ & $0.030 \pm .01$ \\
\hline
\end{tabular}


Table II. Translocation (\%) of PKC in Different Patient Groups

\begin{tabular}{lccc}
\hline & & \multicolumn{2}{c}{ Antigens/Mitogens } \\
\cline { 3 - 4 } Groups & PMA & MAG & CHO \\
\hline TA & $75.0 \pm 7.8^{* *}$ & $8.8 \pm 2.8$ & $6.79 \pm 2.43$ \\
ARF & $63.7 \pm 9.8^{* *}$ & $60.5 \pm 7.6^{* *}$ & $60.1 \pm 17.5^{* *}$ \\
Controls & $36.0 \pm 6.4$ & $15.3 \pm 4.5$ & $5.5 \pm 1.03$ \\
\hline
\end{tabular}

$*^{* *} p<0.001$ compared to controls

Table III. Intracellular Calcium Levels in nanomoles/1 Using Fluorescent Probe Fura 2 AM (Mean \pm SD)

\begin{tabular}{llllll}
\hline \multicolumn{2}{c}{ Group } & \multicolumn{1}{c}{ Basal } & \multicolumn{1}{c}{ PHA } & \multicolumn{1}{c}{ MAG } & \multicolumn{1}{c}{ CHO } \\
\hline TA & 0 & $177.07 \pm 12.56^{* *}$ & $291.60 \pm 17.83^{* *}$ & $176.67 \pm 12.29$ & $177.43 \pm 18.65$ \\
& 3 & $168.0 \pm 12.31^{* *}$ & $277.87 \pm 21.36^{* *}$ & $176.15 \pm 17.10$ & $167.88 \pm 11.98$ \\
ARF & 0 & $205.2 \pm 22.96^{* *}$ & $302.32 \pm 31.6^{* *}$ & $370.30 \pm 30.48^{* *}$ & $297.77 \pm 34.37^{* *}$ \\
& 3 & $156.41 \pm 5.7^{* *}$ & $202.10 \pm 11.56^{* *}$ & $265.43 \pm 18.93^{* *}$ & $204.11 \pm 14.83^{* *}$ \\
\multicolumn{2}{c}{ Controls } & $112.83 \pm 10.60$ & $175.66 \pm 8.23$ & $139.95 \pm 5.03$ & $134.38 \pm 7.03$ \\
\hline
\end{tabular}

$* * p<.001 ; \mathrm{TA}=$ Takayasu's arteritis; $0=$ on first examination; $3=$ three months follow up; ARF $=$ acute rheumatic fever; $\mathrm{MAG}=$ streptococcal membrane antigen; $\mathrm{CHO}=$ streptococcal carbohydrate; PHA = phytohaemagglutanin.

Table IV. cAMP Levels in T Cells (moles/million cells)

\begin{tabular}{lll}
\hline Group & Basal & PHA stimulation \\
\hline TA & $0.508 \pm 0.042$ & $1.12 \pm 0.109^{*}$ \\
ARF & $0.47 \pm 0.29$ & $1.26 \pm 0.24^{*}$ \\
Controls & $0.56 \pm 0.2$ & $1.54 \pm 0.07$ \\
\hline
\end{tabular}

$*_{p}<0.05$ compared to controls.

found to be significantly higher $(p<0.01)$ in TA $(177.07 \pm 12.56 \mathrm{nmoles} / l)$ as compared with the controls (112.83 $\pm 10.60 \mathrm{nmoles} / l)$. When a nonspecific stimulator of T cells, PHA, was added to the cells it showed a marked increase to $299.60 \pm 17.83 \mathrm{nmoles} / l$ in TA as compared to controls (175.66 \pm 8.23 nmoles/ l) (Table III). The difference between the two is significant $(p<0.001)$. Addition of both the membrane and carbohydrate streptococcal antigens had no effect in the TA group while there was a significant increase in the rheumatic fever group. cAMP levels: Basal level of cAMP in TA $(0.508 \pm 0.92 \mathrm{p} \mathrm{mols} / \mathrm{million}$ cells $)$ was significantly $(p<0.01)$ lower than in the controls $(0.566 \pm 0.02 \mathrm{p}$ mols $/ \mathrm{mil}-$ lion cells). On stimulation with PHA the levels remained lower than in the control group (Table IV).

\section{Discussion}

There have been various pointers towards immunologic aberrations in the pathogenesis of Takayasu arteritis. Well recognized immunologic diseases such as 
SLE, rheumatoid arthritis and ankylosing spondylosis have been associated with this. Changes in immunoglobulins and complement levels with the possibility of immune complex formation have been described. ${ }^{11)}$ Scott et al ${ }^{12)}$ demonstrated an increased number of activated $\mathrm{T}$ cells and an increase in in vitro cytotoxicity against cultured umbilical cord endothelial cells. In our earlier study we found an increased number of CD4 $\mathrm{T}$ cells and a disturbed ratio of CD4 and CD8 T lymphocytes. ${ }^{25)}$ There was also an increase in blast transformation to nonspecific antigens as well as purified human aortal antigen. However, not much information is available about the various intracellular signal transductions at the cellular level. In this study we have found the changes in protein kinase $\mathrm{C}$ and intracellular calcium that ultimately lead to stimulation and proliferative response to various mitogens.

We have found that even the basal PKC and intracellular calcium are increased as compared with the controls $(p<0.001)$ suggesting that the cells are in a state of stimulation. On stimulation with the nonspecific mitogen, PHA, and the intracellular activator, PMA, there was a further increase in both. It is of interest that neither the membranes nor the carbohydrate streptococcal antigens produced any change in the PKC or intracellular calcium in TA, thus to a great extent dispelling the suspicion of streptococcal infection as one of the causes of TA. Protein kinase $\mathrm{C}$ is mostly present in cytoplasm and is translocated to plasma membrane in response to DAG. ${ }^{26)}$ In our study we also found that pharbol myristate acetate (PMA), an analogue of DAG, induced a significant translocation of PKC to the membrane fraction. There was no translocation with either of the streptococcal antigens. On the other hand a group of patients with acute rheumatic fever studied simultaneously showed a very significant change.

The hydrolysis of phosphoinositide diphosphate results in the formation of DAG as well as another messenger inositol triphosphate (IP3). The formation of IP3 induces mobilization of free calcium from intracellular pools. ${ }^{26)}$ The intracellular calcium levels in our study were increased both in the unstimulated cells as well as after stimulation with PHA. There was a positive correlation between the levels of PKC and intracellular calcium $(r=0.71, p<0.05)$ showing the intracellular signal system working in a cascade fashion. This indicates the cells to be in an activated stage, as was found by Scott et al. ${ }^{12}$.

We restudied the patients 3 months after treatment but there was no significant change in either of the parameters. It is possible that 3 months is too short a period to detect any change or that the basic cellular pathology is not likely to change with treatment.

What may be the initiating event leading to the change in the $\mathrm{T}$ lymphocytes? Neither tuberculosis nor streptococcal infections seem to explain the picture, and our earlier findings ${ }^{25\rangle}$ seem to suggest an autoimmune phenomenon. 
Once there is a stimulation of the TCR receptor on the T cells, it would start the chain reaction of intracellular signals such as increases in protein kinase $\mathrm{C}$ and calcium resulting in proliferation of lymphocytes. The finding of low cAMP levels further supports this chain of events. The presence of a genetic predisposition and expression of heat shock protein on the aortal endothelial cells has been shown recently by Seko et al. ${ }^{27)}$ Thus prediposed vascular endothelial cells seem to attract stimulated lymphocytes to initiate the inflammatory process.

\section{REFERENCES}

1. Davy J: Researches, Physiological and Anatomical, London, Smith Elder, 1: 426, 1839

2. Savory WS: A case of a young woman in whom the main arteries of both upper extremities and of the left side of the neck were completely obliterated. Med Chir Trans 39: 205, 1856

3. Kussmaul A: Zwei Falle von spontaner allmahlicher Verschliessung grosser Halsarterienstamme. Ditsch Kin 24: 461, 1872

4. Sharma BK, Sagar S, Singh AP, Suri S: Takayasu's arteritis in India. Heart Vessels (Suppl) 7: 37, 1992

5. Dong Z, Li S, Lu X: Percutaneous transluminal angioplasty for renovascular hypertension in arteritis; experience in China. Radiology 162: 477. 1987

6. Vinijchaikul K: Primary arteritis of the aorta and its main branches. Am J Med 43: 15, 1967

7. Koide K: Takayasu's arteritis in Japan. Heart Vessels (Suppl) 7: 48, 1992

8. Birke G, Ejrup B, Orhagen E: Pulseless disease; a clinical analysis of 10 cases. Angiology 8: 433, 1957

9. Sandring $\mathrm{H}$, Welin $\mathrm{G}$ : Aortic arch syndrome with special reference to rheumatoid arteritis. Acta Med Scand 170: 1, 1961

10. Ask-Upmark E: On the pulseless disease outside of Japan. Acta Med Scand 149: 161, 1954

11. Gupta S: Surgical and immunological aspects of Takayasu's disease. Annu R Coll Surg Engl Sep 63: 325,1981

12. Scott DG, Salmon M, Scott DL, Blann A, Bacon PA, Walton KW, Oakland SD, Saney GF: Takayasu's arteritis; a pathogenetic role for cytotoxic T lymphocytes. Clin Rheumatol 5: 517, 1986

13. Nishizuka Y: Intracellular signalling by hydrolysis of phospholipids and activation of protein kinase $\mathrm{C}$. Science 258: 607, 1992

14. Ishikawa K: Diagnostic approach and proposed criteria for the clinical diagnosis of Takayasu's arteriopathy. J Am Coll Cardiol 12: 964, 1988

15. American Heart Association Council on Rheumatic Fever and Rheumatic Heart Disease: Jones' criteria (revised) for guidance in the diagnosis of rheumatic fever. Circulation 69: 204A, 1984

16. Friemer EH, Zabriskie JB: An immunological relationship between the cell (protoplast) membrane of the group A streptococci and the sarcolemma of cardiac muscle. in Gurrent Research on Group A Streptococcus, ed by Caravano R, Experta Medica Foundation, Amsterdam, p 1451968

17. Heymer B, Schieifer KH, Read SE, Zabriskie JB, Krause RM: Detection of antibodies to bacterial cell wall peptidoglycan in human sera. J Immunol 117: 23, 1976

18. Dische Z, Shettles LB: A specific colour reaction of methyl pentosis and spectrophotometric method for their determination. J Biol Chem 175: 596, 1948

19. Rondle CJM, Morgan WTJ: The determination of glucosamine and galactosamine. Biochem J 61: 585,1955

20. Fuller AT: The formamide method for the extraction of nonhaemolytic streptococci. Br J Exp Pathol 19: 130,1938

21. Boyum A: Separation of lymphocytes from blood and bone marrow. Scand J Clin Lab Invest 97: 77, 1968

22. Julius MH, Simpson E, Herzenberg LA: A rapid method for isolation of functional thymus derived 
murine lymphocytes. Eur J Immunol 3: 645, 1973

23. Yamauchi $Y$, Nagasawa $K$, Mayumi $T$, Horiuchi $T$, Niho $Y$ : Activation of protein kinase $C$ induces differentiation in human $\mathrm{T}$ lymphoblastic cell lines Moet-3. Br J Cancer 60: 15, 1989

24. Hofman B, Moller J, Langhoff E, Jakobsen KD, Odum N, Dickmeiss E, Ryder LP, Thastrup O, Scharffo, Foder B, Platz P, Peterson C, Mathiesen L, Jensen TH, Skinhoj P and Svej Gaard A: Stimulation of AIDS lymphocytes with calcium ionophore (A23187) and phorbol ester (PMA); studies of cytoplasmic free calcium, IL-2 receptor expression, $\mathrm{L}-2$ production and proliferation. Cellular Immunol 119: 14, 1989

25. Sagar S, Ganguly NK, Koicha M, Sharma BK: Immunopathogenesis of Takayasu arteritis. Heart Vessels (Suppl) 7: 85, 1992

26. Berridge M: Inositol triphosphate and diacylglycerol as second messengers. Biochem J 220: 345, 1984

27. Seko Y, Minota S, Kawasaki A, Shinkai Y, Maeda K, Yagita H, Okumura K, Sato O, Takagi A, Tada Y, Yazaki Y: Perforin-secreting killer cell infiltration and expression of a $65-\mathrm{kD}$ heat-shock protein in aortic tissue of patients with Takayasu's arteritis. J Clin Invest 93: 75, 1994 